\title{
9 Intercultural Communication and the Possibility of English as a Lingua Franca
}

\author{
John $0^{\prime}$ Regan
}

\section{Historical Prolegomena}

To which marts, that English men call fayres, Ech nation oft maketh her repayres: English, and French, Lombardes, Jennoyes, Catalones, thedre they take her wayes: Scots, Spaniards, Irishman there abides, With great plenty bringing of sale hides. (Richard Haklyut, 1589/1927, The Principal Navigations Voyages Traffiques and Discoveries of the English Nation, vol. 1: 187)

When hailed by another ship, pirates, who were multinational in origin, usually answered that they came 'from the seas,' not from any particular country. Some pirates explained to captives that they had 'sold their nation' for booty. They made the point with brutal clarity after the declaration of war against Spain ... in March 1719, when the British admiralty and royal officials throughout the Americas desperately hoped that pirates would come in, accept the King's commissions, and go back to sea as privateers. (Marcus Rediker, 2004, Villains of all Nations: Atlantic Pirates and the Golden Age: 8)

Multiethnic and multinational crews had to work together and fight together in spite of language differences; Spaniards had to be interrogated, used as pilots and traded with; and Indians were needed as guides and allies: all things were hindered without clear communication. For the buccaneer, the addition of another tongue was as natural and necessary as knowing the difference between taking in, casting off, and letting go. 
(Benerson Little, 2007, The Buccaneer's Realm. Pirate Life on the Spanish Main, 1674-1688: 150)

Now every body, excepting those situated in and near the windows, began to grow outrageous, and many delirious. Water, Water became the general cry. And the old Jemmautdaar, before mentioned, taking pity on us, ordered the people to bring some skins of water, little dreaming, I believe, of its fatal effects. This was what I dreaded. I foresaw it would prove the ruin of the small chance left us, and essayed many times to speak to him privately to forbid it being brought; but the clamour was so loud, it became impossible, and the water appeared. (John Zephaniah Holwell, 1764, A Narrative of the Deplorable Deaths of the English Gentlemen who were Suffocated in the Black Hole in Fort William, at Calcutta, June 1756: 395)

For a laugh, our captors would tell us every now and then: 'It'll be two or three days, or a week, and then you'll be free in Italy.' It was just to see our desperation when they added the word "Inshallah" (God willing). It was their way of lying without seeming to lie. (Dominico Quirico, the Observer, 15 September 2013: 30)

\section{ELF and the Adequacy of a Concept}

I see my role here in the nature of an intervention within a set of sociolinguistic positions, arguments, assumptions, procedures, instruments and practices which have been lexicalized in the study of applied linguistics as 'English as a lingua franca', or ELF; a concept which has been expressed in this book variously as 'a new field of research that accounts for an empirically based and theoretically informed understanding of how English is used today in an increasing number of contexts' (Holmes \& Dervin, 2016: 4); 'a communicative situation dominated by people who don't have the language in question as their first or early second language' (Risager, 2016: 37); 'a construct that refers to mutual engagement, joint enterprise and shared repertoire' (Bjørge, 2016: 116); 'a contact language spoken by interactants that do not share a common L1' (Jenks, 2016, 97); 'the dynamic and fluid manner in which form, function and context are constructed in intercultural communication' (Baker, 2016: 70); and a phenomenon which is 'highly fluid and hybridized, and [drawing] upon multiple linguistic resources that are both global and local in scope, to construct novel speech forms' (Henry, 2016: 184). Let me begin with two questions. The first is, What would the world have to be like for ELF to be possible? This is a question which is qualitatively different to a second question, which is, What would the world have to be like for lingua franca Englishes to be possible?). I believe that the 
answers to these two questions are different, and that they lead to different conclusions about the history and dissemination of English(es) in the world. This is the subject which I wish to address in this chapter.

The reader will have noticed that the term ELF is here purposely placed 'under erasure' (Spivak, 1976: xvii), with a line drawn through it. This is in order to signal how this term is not just provisional, but inadequate in relation to the sociolinguistic complexity of global and local uses of 'English' in the world. As intimated in the last sentence, the same can also be said of the term 'English', a term which not only hides a multitude of varieties within it (Blommaert, 1998), but in a world increasingly acknowledged to be populated by 'Englishes' (Kachru, 1985), and with an entire 'World Englishes' field dedicated to their research, has long been seen as erroneous and problematic. The same can also be said for the word 'culture'. There is evidently a wider discussion to be had - and which is being had - about the adequacy of all these terms (see Blommaert, 1998, 2010; Holliday, 2010; Pennycook, 2007; Rajagopalan, 2012), but in the space I have here I will confine myself to ELF, and so in this chapter, only this term will appear with a line drawn through it.

On the one hand, ELF is an hypostatization (O'Regan, 2014); that is, its very use implies something fixed and stable - having the property of concreteness - and notwithstanding the widespread statements of ELF supporters disputing this. On the other hand, when persons of different linguistic and community or cultural backgrounds meet together for whom 'English' is not a mother tongue, they are evidently not speaking 'English', as this too suggests something which is uniform, or 'centripetal', in relation to an implied hegemonic norm (Rajagopalan, 2012). Instead, it might be more accurate to say that they are speaking Englishes together, or something more 'centrifugal' (Rajagopalan, 2012); which is to say, that rather than speaking ELF (or even, as is sometimes claimed, 'in EŁF'), or faithfully reproducing standardized native-like inner-circle norms (Gao, 2014), which on the face of it are also 'Englishes' (American, Welsh, Irish, Australian, etc.), they are speaking one or other forms of L1-inflected English (here still a problematic term). Although that is not to deny that a certain amount of modelling of imagined native speaker (NS) norms may be in process amongst the speakers as well, with greater or lesser degrees of success and, depending on the subjective judgment of the hypothetical hearer, whether native or not. But here again as I write these sentences I am conscious in the very inscription of the word of the problem which makes ELF, like the sign, 'that ill-named thing' (Derrida, 1976: 19). For in contradistinction to its supporters' claims about the plurilithicism, hybridity and originality of their object of knowledge, 'ELF' is introduced into this complexity as an hypostatized form - reified, 
settled, resolved, fixed, sedimented, cemented, and finally stamped onto the page: an inked sign in a white landscape.

Much of the foregoing critique rests upon an acceptance that speakers of 'English' in intercultural settings are in fact speaking qualitatively different forms of English to one another, depending on their lifeworld experiences of the language known as 'English' and the individual linguacultural as well as personal backgrounds from which they speak, e.g. Japanese, Italian, Korean, Chinese, Arabic, Portuguese, Spanish or even English. It is an entirely subjective decision as to whether you accept non-native speaker 'English' as a type or style of English, or not. For some, English is a term which must infer an abstracted authority which is able pronounce on what is or is not legitimate English. So that when non-native speakers (NNSs) are said to be speaking 'English', the signified of which their speech is the signifier seems by implication to be a recognized native-speaker norm. So if a Japanese and a Greek are said to be speaking 'English' to one another, the implied signified for this is the native-speaker form of the language. But we could equally say instead that the Japanese speaker is speaking 'English' (that term again) with Japanese characteristics and the Greek is speaking English with Greek characteristics, and if we did accept this, then it could be argued that the speakers are speaking Englishes of slightly - or possibly very - different kinds. Or we might even say that they are speaking lingua franca Englishes or LFEs, but it would be apocryphal to claim that they are speaking ELF: a language variety with no NSs. In the term ELF a different order of signification is in play, and it is one which mimics the type of signification which applies to the term 'English'. That is, as the inscription ELF appears as a trace on the page, $€ \amalg F$ becomes hypostatized as a thing-in-itself and thus simultaneously the universal signified for L2 intercultural communicative encounters.

In drawing attention to the hypostatization of $E \notin F$, and also of English, and by presenting it in this way, I am concerned with a figure which is absent. Namely, the world which would have to be assumed for ELF to be possible - the implied ontology for ELF (Bhaskar, 2008). In relation to this, I wish to maintain a critical stance towards ELF. My objective is not a sedimented mode of enquiry, that is, one which takes ELF as a given object of knowledge and proceeds from that premise; rather, it is an enquiry into the very nature of that sedimentation. The metaphor of sedimentation is appropriate to this discussion when one considers that it infers a settling, fixity, substantiality, density, materiality and, by dint of this, emergence into some form of completeness and permanence - of ELF as 'an emerging English that exists in its own right' (Jenkins, 2007: 2). The capacity of ELF supporters to slide seamlessly between 'ELF with its emphasis on hybridity, innovation 
and accommodation' (Dewey \& Jenkins, 2010: 76) to speaking and writing 'in ELF' in 'ELF settings' which are populated by 'ELF speakers' (e.g. House, 2012: 285; Jenkins, 2013: 38; Jenkins et al., 2011: 302; Mauranen \& MetsäKetelä, 2006: 6) is worthy of comment and arises from an underlying weakness within ELF theory. This weakness proceeds from the reduction of ontology (reality) to epistemology (what can be observed) so that what is presumed to be real is interpreted and understood - or misrecognized - primarily in terms of what is observed.

In other words, in ELF, the mere fact of intercultural communication in 'English' amongst speakers of different L1s is taken as a sufficient basis to be able to speak of an entity that is ELF and to take this as a self-affirmed starting point.

\section{The mythologization of ELF}

The mythologization of ELF proceeds from the implication, in much of the discourse related to it, that non-native speakers (NNSs) of Englishes in the world are in the process of evolving a new variety of English - ELF - with accompanying pragmalinguistic strategies to which these users are incrementally contributing, whether consciously or unconsciously (cf. Cogo \& Dewey, 2012; Jenkins et al., 2011; Seidlhofer, 2011). This implication explains why such great emphasis is placed upon observed empirical linguistic-pragmatic innovations and conjunctions of events in the discourse of speakers engaged in communication in inter- or cross-cultural settings. Building on this perception is the presumption that innovative language forms and creative accommodation techniques are travelling in a consistently uniform and incremental manner from one intercultural setting to another, such that it becomes possible to begin to map the emergence of ELF and its intercultural pragmatics. The assumption of ELF is self-legitimizing and rests on a mythologization in which intercultural encounters in English magically coalesce into communities of shared practice and repertoire (Seidlhofer, 2009) and where speakers, it is claimed, 'skillfully negotiate and co-construct English for their own purposes, treating the language as a shared communicative resource within which they innovate, accommodate and code-switch, all the while enjoying the freedom to produce forms that NSEs (native speakers of English) do not necessarily use' (Jenkins et al., 2011: 297).

My feeling is that such views both exaggerate and oversimplify matters, and that the innovative continuities which are implied as travelling between contexts are projected onto intercultural encounters from an overriding desire to uncover them. If anything, such encounters are marked by linguistic and pragmatic discontinuity - and real-world inequality - so that no one 
encounter is identical to another (Blommaert, 1998); and that where commonalities are observed across settings (e.g. dropping of the third-person 's' or apparently innovative or playful negotiated meaning construction between L2 speakers), these are indicative not of creative and imaginative realizations of $E L F$, or of shared repertoire, but are examples of variants typical of L2 production and also of coincidences between L1 lexico-grammars which are then realized in intercultural interactions in the L2. They are, in addition, examples of what Phipps (2007) has called 'the human struggle to make meaning' (19). Accommodation on this account is not simply the privileged domain of L2 speakers of Englishes in the world, or indeed of speakers of EŁF. The hermeneutic and analytic traditions in philosophy and in linguistics (Gadamer, 1989; Grice, 1975; Habermas, 1984) have shown how accommodation and cooperation are basic to all human communication and action. As Habermas has argued,

The concept of communicative action presupposes language as the medium for a kind of reaching understanding, in the course of which participants, through relating to a world, reciprocally raise validity claims that can be accepted or contested ... For both parties the interpretive task consists in incorporating the other's interpretation of the situation into one's own in such a way that in the revised version 'his' external world and 'my' external world can - against the background of 'our' lifeworld - be relativized in relation to 'the' world, and the divergent situation definitions can be brought to coincide sufficiently. Naturally, this does not mean that interpretation must lead in every case to a stable and unambiguously differentiated assignment. Stability and absence of ambiguity are rather the exception in the communicative practice of everyday life. (Habermas, 1987: 100; my emphasis)

To claim that there is something special, emergent and unique about the way L2 speakers of Englishes communicate with one another in intercultural encounters is to idealize a practice which is basic to human communication, as well as to the interactions observed. In addition, as the above passage indicates, human communication is rarely stable and unambiguous, perhaps more so in the case of lingua franca settings, and processes of communication are forever being constructed anew. A similar point has been made by Pennycook (2010a) and Canagarajah (2007) in relation to what they refer to as 'lingua franca English' (LFE). Pennycook (2010a) argues that the distinction between English as a lingua franca and lingua franca English is important because "the former tends towards an understanding of a pre-given language that is then used by different speakers, while the latter suggests that LFE emerges from its contexts of use' (2010a: 684). He then cites Canagarajah as saying that 'LFE 
does not exist as a system out there. It is constantly brought into being in each context of communication' (Canagarajah, 2007: 91, cited in Pennycook, 2010: 684). In the mindful words of Blommaert (1998),

If 'cultures meet', they usually do so under rather grim socioeconomic circumstances, with a clear societally sanctioned power difference between the various parties involved. It is, from that perspective, also useful to point at the abnormality of many studies of intercultural communication that focus on elite forms of interaction such as business negotiations, technological cooperation, international management or diplomacy [...] In sum, 'culture' in all its meanings and with all its affiliated concepts, is situational. It depends on the context in which concrete interactions occur. Studying speech conventions of certain groups of people, and then contrasting them with those of other groups of people, is of little use to the study of intercultural communication. (http://www.cie.ugent.be/ CIE/blommaert1.htm; my emphasis)

If such enquiry is of little use to the study of intercultural communication, it is also of little use in the study of intercultural interactions which are taken to be realizations of ELF. We should also in this connection remind ourselves that accommodation and cooperation are present in the rejection, oppression and disparagement of the other (cf. Holliday, 2010; Jenks, 2012; Ladegaard, 2012; Phipps, 2014). It has often been presupposed in much of the writing about ELF and about intercultural communication that the objective is what Phipps (2007) has referred to as 'some nirvana of toleration and harmony' (19). Despite this assumption, however, the brute fact remains that around the world people are accommodating and cooperating in the marginalization, oppression and annihilation of one another, and that this is not new but rather has a long history. It is therefore possible to kill the other in ELF while being accommodating at the same time, as demonstrated by the Westgate shopping mall massacre in Nairobi in 2013 and the mass suffocation of 125 members of the multinational East India Company garrison in the 'Black Hole' of Calcutta in 1756. To these events we may add the kidnappings and summary executions of foreign nationals by jihadists in Iraq and Afghanistan over several years and the recent killing of an 'Afghan insurgent' by a British Royal Marine, who dispatched his victim with the words 'There you are. Shuffle off this mortal coil, you cunt. It's nothing you wouldn't do to us' (Mark Townsend, The Guardian, 9 November 2013 ). In addition, we might also note that the Norwegian white supremacist and mass murderer Anders Behring Breivik wrote his online European Declaration of Independence in $\mathrm{LF}$ and would be classed as a proficient $\mathrm{LF}$ user. 


\section{Ontological realism and lingua franca Englishes}

A further distinction which this discussion raises is that the ELF concept is based on an historical narrative (or ontology) in which ELF is misrecognized as original and new. In brief, the narrative is that since 1945 the world has entered a new transformational era of international communication ensuing from globalization, decolonization and the diffusion of the knowledge economy, and that the lingua franca of international communication is a newly emergent, hybridized, plurilithic and deterritorialized form of English which is especially suited to this new era (Dewey, 2007; Dewey \& Jenkins, 2010; Jenkins, 2013; Jenkins et al., 2011; Seidlhofer, 2011). Another aspect of this narrative is that it is often implied that learners of English globally are, without exception, all users, and it is on this basis that NNSs of English outnumber NSs. This may well be so, but its extent depends on the criterion of use that is applied, as not all learners become users. Nevertheless, the assumption in ELF that learners and users are synonymous not surprisingly provides the numerical basis for questioning the legitimacy of standard NS inner circle Englishes as the ideal models for English in classrooms around the world, a point I shall return to below.

The misrecognition which attends ELF is the perception that lingua franca situations in which 'English' (that term again) is selected by participants as the medium of communication are somehow original and new. In ELF, globalization and the specifics of EŁF discourse are, in the words of Blommaert (2010), presented as, 'shockingly new things - as if the world we now live in is a totally new one. It is not' (2010: 16). A perusal of the ELF literature shows that the historiography of ELF is almost entirely confined to the recent past, and mostly since the mid-1990s. To read about ELF is thus to gather the impression that in previous decades and centuries when speakers of different L1s spoke to one another in 'English', they were not speaking EŁF. Indeed, it seems that they were not speaking at all. The neglect of the historicity of English and its intertwinement in the globalization of a capitalist world system that dates to at least the 1600s (Wallerstein, 2004) is a fundamental flaw in an ELF narrative which barely scratches the surface of intercultural uses of 'English' historically. A more diachronic historical perspective shows that LFEs, as I am calling them, have been around for a very long time.

When the English naval explorer Francis Drake commenced his circumnavigation of the globe in 1557, the crew he took with him was multinational, but the language of the ship was what the sailors knew as 'English'. In the 'golden age' of Caribbean and Atlantic piracy from the 1650s to the 1730s, multinational, multi-ethnic and multilingual crews were the norm, and a number of these were commanded by English captains for whom 
Spanish and English would have been shipboard lingua francas. The soldiers who fought in Cromwell's armies during the 'pacification' of Ireland in the 1650s were in part Irish mercenaries whose first language was Irish but who were led by native English-speaking commanders. The English East India Company (EIC) army of the 1600s and 1700s had large numbers of mercenary soldiers amongst its ranks, including Sepoys, French, Dutch and Portuguese. These fought alongside British EIC recruits and under English officers, and were essential to the establishment of British rule in India. The American Revolutionary War of 1775-1783 was fought on both sides in several languages, including English. The language of trade along the China coast from 1750 to at least 1850 was Canton Pidgin English, spoken not only between foreigners and local Chinese in the treaty ports but also between Chinese from different regions of China (Bolton, 2003; Van Dyke, 2005). What this historical sketch shows is that the concept of English, or better still Englishes, being used for lingua franca purposes amongst speakers of different L1s is not in any sense original, creative or especially new; lingua franca Englishes have been in existence for centuries. They are certainly not simply the progeny of a narrow range of modern-day bilingual elites in globally rarefied international business, education, research and leisure domains as appears to be the case in ELF (see Breiteneder, 2009; Ehrenreich, 2011; Kalocsai, 2009; Kankaanranta \& Planken, 2010; Mauranen, 2012).

That these are lingua franca Englishes is key, because speakers of different L1s from different parts of the world carry their lexico-grammars and their lifeworlds with them when they are speaking other languages. That is, if they wish to speak at all, they intend to mean something and to receive meaning in return, and are willing to commit to the struggle to make meaning, regardless of how messy this process may be. These speakers speak and will often write in a form of English which is marked to a greater or lesser extent by their local L1 knowledge and experience, and when they come together in communication with speakers of other L1s, the result is lingua franca Englishes (LFEs), not ELF. Thus we may say that lingua franca Englishes when used in intercultural communication encounters are historical, contemporary, personal and often messy, and that the linguistic pragmatics of LFEs are created anew from one context to another, and not according to an a priori, emergent or incrementally evolving plan. LFEs are necessarily plural, not singular, because the contexts where LFEs are present are plurilingual (i.e. more than one variant or type of English is present). They are also differentiated and stratified in terms of class, race, gender, economy and religion. That is to say that encounters involving LFEs are not confined to globalized and largely White elites in international business, diplomacy and research contexts. The poor, the disenfranchized, the 
ethnically marginalized, and the exploited - the 'McWorkers' of neoliberal economies - are also users of LFEs in intercultural settings. In the world of ELF research, however, these speakers appear to have no voice.

Another reason for preferring LFEs over lingua franca English (LFE) is that 'LFE' is unable to capture simultaneously the singular and the plural of intercultural encounters where more than one variant of English is present, which also includes the personal imprint which each speaker brings to the variant they select. Every encounter is a personal one for each participant in respect of the English he or she chooses to speak - as a variant and idiolectally - as well as a multiple one in respect of the different Englishes drawn upon by all of the participants together. In this manner 'LFE' potentially suffers from the same problem as ELF. It follows from this that if terms such as 'LFE' or 'LFE context' are to be employed, the double meaning of 'LFE' needs to be somehow taken into account and foregrounded.

A similar argument might have been made for ELF, but it is already too late for that. The term has been inscribed into text and formulaic compound neologisms a million times and more, and so what remains is the darkening cloud of the hypostatized form only: 'ELF speakers', 'ELF settings', 'ELF encounters', 'ELF users', 'ELF interactions', 'ELF accommodation', 'ELF creativity', 'ELF innovation', 'written $E \Perp F$ ', 'spoken $E \amalg F$ ', 'ELF error', and so on. The term has slid into the linguistic collective consciousness and now, in Marx's words, 'weighs like a nightmare on the brains of the living' (Marx, 1978 [1852]: 595).

The supposed radicalism of the ELF project is similarly overstated. The ELF case proceeds from a liberal-idealist rationalism and acquiescence to the geo-capitalist status quo, which issues from its incapacity to critique, or even name, capitalism as a primary agent in determining the global distribution of economic and linguistic resources, and thus individuals' life chances as well. Instead, the world system is taken as given, and economic, gendered, racial, religious and class inequalities within and between the populations of nation states are discounted in favour of a focus on lingua franca forms as ideologically neutral and self-emancipating and, less promisingly, as geoculturally Eurocentric and the property of cosmopolitan bilingual elites. ELF as a political project thus provides a pillar of support to mobile capital in the reproduction of global class stratifications along linguistic lines. To put this another way, those who have most access to intercultural lingua francas and the most opportunity to use them are those with the highest quotients of economic, social, cultural and linguistic capital (Bourdieu, 1986).

It is therefore not surprising to find that the NNSs who have the most native-like lexico-grammars in the L2 are from this group. This may appear contradictory, given that a principal focus of ELF research is to champion the claims of the NNS in the face of the hegemony of NS norms. The problem 
here lies in the kinds of groups such research prefers to champion. As I have indicated, these are not the 'ordinary' or the marginalized of the world, but elites (albeit stratified), as the ELF research data regularly shows. Some of these users may be entirely satisfied with their non-standard and 'non-native like' modes of articulation in speaking (but possibly less so in writing). However, capital dictates that this is an insufficient basis for gaining access to the higher echelons of international global power - whether in education, business, finance, philosophy or diplomacy. To reach this level of access, nothing less than standardized (and mythologized) native-speaker-like English will do.

When I saw [Christine] Lagarde speak last week, she was wearing a scarf tied in a perfect geometric circle, holding her glasses in one hand as a prop, and standing as erect as you'd expect from a former member of France's synchronized swimming team. But the salient fact about her is her English, absorbed over 25 years in the US. Lagarde was an exchange student at a Maryland private school, interned on Capitol Hill, and eventually ran the law firm Baker \& McKenzie. Her English is key to why everyone almost instinctively turned to her to replace Dominique StraussKahn at the IMF. The Economist, house magazine of the global Anglophone elite, called her "a superb communicator, a good negotiator and, by all accounts, an excellent manager". Note which phrase came first. Lagarde is a woman for our times. To make it very big nowadays, speaking English usually isn't enough. You need perfect English. (Simon Kuper, 'Something in the way she speaks...', The Financial Times, 24 June 2011)

Quite apart from the preoccupations of senior officials in the IMF and their admirers, worldwide, people who have access to English, and who care about this, believe that their life chances and those of their children will be affected by the kind of English that they learn, and, despite widespread and well-documented local appropriations in such diverse areas such as hip hop and online chat rooms (Pennycook, 2007, 2010b; Jenks, 2012), usually care little about the democratising niceties of speaking local or hybridized Englishes, much as this may be welcomed by those of us who write about these things. Similarly, their governments believe this too. This is why there is such a clamour for NS models of English around the world; why tests based on NS models predominate in school and university examinations; why international testing systems such as IELTS, TOEIC and TOEFL (which are based on NS models) are aggressively promoted; why husbands and wives have been separated so that their children can move to an Anglophone country and acquire native-like competence; and why NS teachers continue to be favoured 
over NNS locals, particularly by parents who can afford to make the choice for their children - notwithstanding the ELF argument that the globalized spread of English puts into question the legitimacy of NS Englishes as the ideal models in English language classrooms around the world. That this is a result of the capitalist world system appears to be lost on ELF advocates, and this would explain the absence of any critique to this effect.

By utilizing Bhaskar's division of reality into the real, the actual and the empirical (Bhaskar, 2008) and applying it to ELF, it becomes apparent how ELF operates with an ontology which misses the real causal mechanisms (of globalized capital) which are responsible for the actual events (worldwide social and class distributions of Englishes) as well as the empirical experiences (uses of LFEs in intercultural contexts) which make up the three domains. ELF does so by a reduction of the real and the actual to the empirical (epistemic fallacy - interpretation of being in terms of knowing) such that reality is misrecognized by means of data gleaned from empirical observations. In other words, the empirical becomes the lens according to which the real world is distorted, and an imaginary world free of ideology and capital is set in its place. The act, in ELF, of making the empirical take ideological precedence over the domains of the actual and the real thus leads to a form of transcendental idealism or idealist rationalism (Bhaskar, 2008) in which the researched intercultural encounters of ELF are fetishized and the reality of Englishes in a structurally inegalitarian world is obscured. Until ELF theory is able to overcome this reduction, and recognizes the misrecognition, the prospect that through its arguments alone there ever could be a significant redistribution of language resources and capital away from elites in the world system towards those systematically disadvantaged as well as linguistically disparaged by it seems illusory.

\section{Concluding Remarks}

It is evident even in the writing of this text that there is a problem with terms such as 'English' and 'culture' as well as with 'ELF' in the interconnected domains of applied linguistics and intercultural communication, and that writing about them is always fraught with ambivalence. Perhaps all three terms ought to have been placed under erasure. I have not done so, and this lack is an anomaly in this text. Derrida (1978) makes the point that in order to critique the sign there is no getting away from using the sign, even as it is 'that ill-named thixg'. In the same way, it seems difficult as well as impractical - for historical reasons - to move away from talking about 'English' and 'culture(s)' and much else in human experience in a way that 
does not also simultaneously invoke an essentialist and transcendental signified. It seems a necessary complicity to perform this invocation, even as we recognize its incommodity.

If this is the case, then why spend time deconstructing the signifier that is ELF? One good reason is that the twin concepts of 'English' and 'culture' have been the subject of much intense deliberation and critique with regard to the essentialisms which they have historically set in train, as the work of many authors in applied linguistics and intercultural communication have shown. Not so with the construct that is ELF, which seems to have become its own self-affirming principle. It is unfortunate - and indicative of a seeming wider paranoia - to note that such is the apparent gorgon-like hold of ELF on the collective consciousness that those who agitate in its favour appear simply to view those who do not as enemies, reactionaries, unbelievers, wilful misinterpreters and spoilers - a reaction not dissimilar to that which is delivered up to those who question the motives of cults and other fundamentalist groups. In addition, due at least in part to the necessary complicity already mentioned, EŁF has also inevitably become present in the discourse of its retractors, as well as of those such as language teachers and students who find themselves simply confronted with the term. Hence my decision in this chapter to place it under erasure so that its provisional and sociolinguistically inadequate nature can be clearly signalled and explored. In this way, in the act of making this mark, perhaps we may for a while free our thought from its heavy inscriptional form and so, as Derrida (1976: 158) suggests, open a new reading.

\section{References}

Baker, W. (2016) Culture and language in intercultural communication, English as a lingua franca and English language teaching: points of convergence and conflict. In P. Holmes and F. Dervin (eds) The Cultural and Intercultural Dimensions of English as a Lingua Franca (pp. 70-92). Bristol: Multilingual Matters.

Bhaskar, R. (2008) A Realist Theory of Science. London: Verso.

Bjørge, A.K. (2016) Conflict talk and ELF communities of practice. In P. Holmes and F. Dervin (eds) The Cultural and Intercultural Dimensions of English as a Lingua Franca (pp. 114-133). Bristol: Multilingual Matters.

Blommaert, J. (1998) Plenary lecture, Lernen und Arbeiten in einer international vernetzten und multikulturellen Gesellschaft, Expertentagung Universität Bremen, Institut für Projektmanagement und Witschaftsinformatik (IPMI), 27-28 February 1998. See http://www.cie.ugent.be/CIE/blommaert1.htm (accessed 19 November 2013).

Blommaert, J. (2010) The Sociolinguistics of Globalization. Cambridge: Cambridge University Press.

Bolton, K. (2003) Chinese Englishes: A Sociolinguistic History. Cambridge: Cambridge University Press.

Bourdieu, P. (1986) The forms of capital. In J. Richardson (ed.) Handbook of Theory and Research for the Sociology of Education (pp. 241-258). New York: Greenwood. 
Breiteneder, A. (2009) English as a lingua franca in Europe: An empirical perspective. World Englishes 28 (2), 256-269.

Canagarajah, A.S. (2007) The ecology of global English. International Multilingual Research Journal 1 (2), 89-100.

Cogo, A. and Dewey, M. (2012) Analysing Engish as a Lingua Franca: A Corpus-Driven Investigation. London: Continuum.

Derrida, J. (1976) Of Grammatology. Baltimore: Johns Hopkins University Press.

Derrida, J. (1978) Writing and Difference. London: Routledge.

Dewey, M. (2007) English as a lingua franca: An interconnected perspective. International Journal of Applied Linguistics 17 (3), 332-354.

Dewey, M. and Jenkins, J. (2010) English as a lingua franca in the global context: Interconnectedness, variation and change. In M. Saxena and T. Omoniyi (eds) Contending with Globalization in World Englishes (pp. 72-92). Bristol: Multilingual Matters.

Ehrenreich, S. (2011) The dynamics of English as a lingua franca in international business: A language contact perspective. In A. Archibald, A. Cogo and J. Jenkins (eds) Latest Trends in ELF Research (pp. 11-34). Newcastle upon Tyne: Cambridge Scholars.

Gadamer, H-G. (1989) Truth and Method. New York: Crossroad.

Gao, Y. (2014) Faithful imitator, legitimate speaker, playful creator and dialogical communicator: Shift in English learners' identity prototypes. Language \& Intercultural Communication 14 (1), 59-75.

Grice, H.P. (1975 ) Logic and conversation. In P. Cole and J.L. Morgan (eds) Syntax and Semantics. London: Academic Press.

Habermas, J. (1984) The Theory of Communicative Action: Reason and the Rationalisation of Society (vol. 1). London: Heinemann.

Habermas, J. (1987) The Philosophical Discourse of Modernity. Cambridge: Polity Press.

Haklyut, R. (1589/1927) The Principal Navigations Voyages Traffiques and Discoveries of the English Nation (vol. 1). London: J. M. Dent \& Sons.

Henry, E.S. (2016) The local purposes of a global language: English as an intracultural communicative medium in China. In P. Holmes and F. Dervin (eds) The Cultural and Intercultural Dimensions of English as a Lingua Franca (pp. 180-202). Bristol: Multilingual Matters.

Holliday, A. (2010) Ideology and Intercultural Communication. London: Routledge.

Holmes, P. and Dervin, F. (2016) Introduction - English as a lingua franca and interculturality: beyond orthodoxies. In P. Holmes and F. Dervin (eds) The Cultural and Intercultural Dimensions of English as a Lingua Franca (pp. 1-32). Bristol: Multilingual Matters.

Holwell, J. Z. (1764). A narrative of the deplorable deaths of the English gentlemen who were suffocated in the black hole in Fort William, at Calcutta, June 1756. In J. Z. Holwell and Friends (eds) India Tracts (pp. 252-276). London: T. Becket \& T. A. de Hondt.

House, J. (2012) (Im)politeness in cross-cultural encounters. Language and Intercultural Communication 14 (4), 284-301.

Jenkins, J. (2007) English as a Lingua Franca: Attitude and Identity. Oxford: Oxford University Press.

Jenkins, J. (2013) English as a Lingua Franca in the International University. London: Routledge.

Jenkins, J., Cogo, A. and Dewey, M. (2011) Review of developments into research into English as a lingua franca. Language Teaching 44 (3), 281-315.

Jenks, C. (2012) Doing being reprehensive: Some interactional features of English as a lingua franca in a chat room. Applied Linguistics 33 (4), 386-405.

Jenks, C. (2016) Talking cultural identities into being in ELF interactions: an investigation of international postgraduate students in the United Kingdom. In P. Holmes and 
F. Dervin (eds) The Cultural and Intercultural Dimensions of English as a Lingua Franca (pp. 93-113). Bristol: Multilingual Matters.

Kachru, B. (1985) Standards, codification and sociolinguistic realism: The English language in the outer circle. In R. Quirk and H.G. Widdowson (eds) English in the World: Teaching and Learning the Language and Literatures (pp. 11-30). Cambridge: Cambridge University Press.

Kalocsai, K. (2009) Erasmus exchange students: A behind the scenes view into an ELF community of practice. Journal of Applied Language Studies 3 (1), 25-49.

Kankaanranta, A. and Planken, B. (2010) BELF competence as business knowledge of internationally operating business professionals. Journal of Business Communication 47 (4), 380-407.

Kuper, S. (2011) Simon Kuper, Something in the way she speaks..., The Financial Times, 24 June 2011.

Ladegaard, H. (2013) Beyond the reach of ethics and equity? Depersonalisation and dehumanisation in foreign domestic helper narratives. Language \& Intercultural Communication 13 (1), 44-59.

Little, B. (2007) The Buccaneer's Realm. Pirate Life on the Spanish Main, 1674-1688. Washington: Potomac Books.

Marx, K. (1978/1852) 18th Brumaire of Louis Bonaparte. In R.C. Tucker (ed.) The MarxEngels Reader (pp. 594-617). New York: Norton.

Mauranen, A. (2012) Exploring ELF: Academic English Shaped by Non-native Speakers. Cambridge: Cambridge University Press.

Mauranen, A. and Metsä-Ketelä, M. (2006) Introduction. Nordic Journal of English Studies Special Issue: English as a Lingua Franca 5 (2), 1-8.

O’Regan, J.P. (2014) English as a lingua franca: An immanent critique. Applied Linguistics 35 (5), 533-552.

Pennycook, A. (2007) Global Englishes and Transcultural Flows. London: Routledge.

Pennycook, A. (2010a) 'The future of Englishes: One, many or none?' In A. Kirkpatrick (ed.) The Routledge Handbook of World Englishes (pp. 673-688). London: Routledge.

Pennycook, A. (2010b) Language as a Local Practice. London: Routledge.

Phipps, A. (2007) Learning the Arts of Linguistic Survival: Languaging, Tourism, Life. Clevedon: Channel View Publications.

Phipps, A. (2014) 'They are bombing now': 'Intercultural dialogue' in times of conflict. Language \& Intercultural Communication 14 (1), 108-124.

Quirico, D. (2013) My 150-day ordeal as a hostage of Syria's rebels. The Observer, 15 September.

Rajagoplan, K. (2012) 'World English' or 'World Englishes'? Does it make any difference? International Journal of Applied Linguistics 22 (3), 374-391.

Rediker, M. (2004) Villains of all Nations: Atlantic Pirates and the Golden Age. London: Verso.

Risager, K. (2016) Lingua francas in a world of migrations. In P. Holmes and F. Dervin (eds) The Cultural and Intercultural Dimensions of English as a Lingua Franca (pp. 33-49). Bristol: Multilingual Matters.

Seidlhofer, B. (2009) Common ground and different realities: World Englishes and English as a lingua franca. World Englishes 28 (2), 236-245.

Seidlhofer, B. (2011) Understanding English as a Lingua Franca. Oxford: Oxford University Press. Spivak, G.C. (1976) Translator's Preface, in J. Derrida, Of Grammatology. Baltimore: Johns Hopkins University Press.

Van Dyke, P.A. (2005) The Canton Trade. Hong Kong: Hong Kong University Press.

Wallerstein, I. (2004) World Systems Analysis: An Introduction. Durham and London: Duke University Press. 